\title{
Energy Efficiency and Emissions of a Natural-Draft Wood Pellets Gasifier Compared to Charcoal Cookstoves in Kenya
}

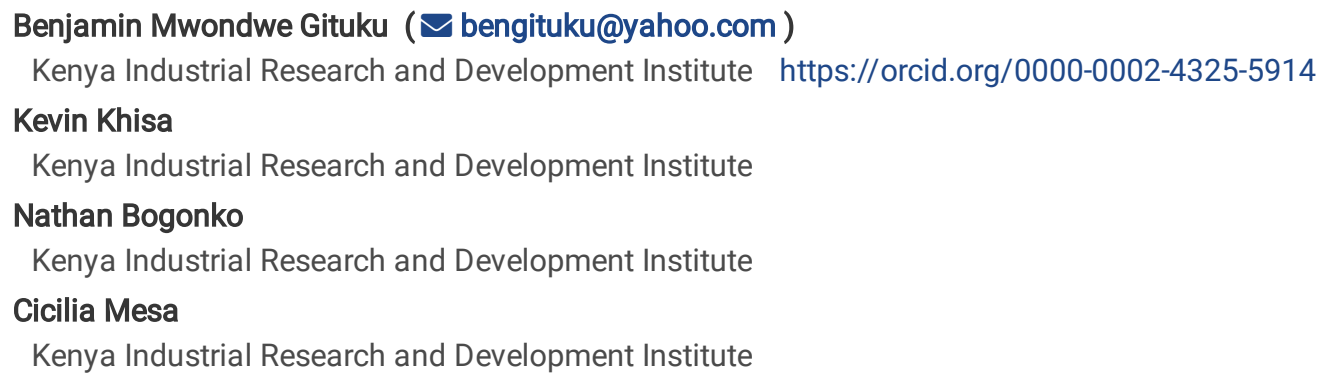

\section{Research Article}

Keywords: Natural-draft gasifier, biomass pellets, charcoal cookstoves, woodfuel, energy efficiency, emissions

Posted Date: March 3rd, 2021

DOI: https://doi.org/10.21203/rs.3.rs-198040/v1

License: (c) (i) This work is licensed under a Creative Commons Attribution 4.0 International License. Read Full License 


\section{Abstract}

The conversion of biomass to make charcoal fuel is an inefficient process that leads to immense energy losses along the value chain. We compared the energy efficiency and emissions of Gastov206, a natural draft TLUD gasifier cookstove using two sizes of wood pellets, as an alternative to two contemporary charcoal stoves in Kenya.

A laboratory test showed that more energy in the fuel was lost by the charcoal cookstoves $(69 \%)$ compared to the pellet gasifier cookstove (31\%). The pellet gasifier cookstove had high thermal efficiency and cooking power (65-73\%, 0.95-1.13 kW) compared to the charcoal cookstoves $(27-35 \%, 0.68-0.89 \mathrm{~kW})$. During the test, Gastov206 converted pellets-to-char at a ratio of $25 \%$ and a rate of $3 \mathrm{~g} / \mathrm{min}$. These findings indicate that when biomass is converted to pellets rather than charcoal, and cooking continues over the burning char generated by the gasifier cookstove, energy currently being wasted converting wood-to-charcoal can be avoided.

Gastov206 using pellets showed lower $\mathrm{CO}$ emission (4.46-5.47 g/MJ $\mathrm{MJ}_{\mathrm{d}}$ and $0.27-0.39 \mathrm{~g} / \mathrm{min}$ ) compared to charcoal cookstoves (20.82$24.36 \mathrm{~g} / \mathrm{MJ}_{\mathrm{d}}$ and $\left.0.89-1.35 \mathrm{~g} / \mathrm{min}\right)$. PM2.5 emission by Gastov206 (52.35-61.50 mg/ $\mathrm{MJ}_{\mathrm{d}}$ and $3.21-4.37 \mathrm{mg} / \mathrm{min}$ ) was not significant different compared to charcoal stoves (40.81-41.13 $\mathrm{mg} / \mathrm{MJ}_{\mathrm{d}}$ and $\left.1.69-2.35 \mathrm{mg} / \mathrm{min}\right)$.

Laboratory results show that natural-draft gasifier cookstoves using pellets can be studied further in kitchens as an alternative to charcoal cookstoves since they are potentially more energy-efficient.

\section{Introduction}

\subsection{Background}

Biomass is the largest energy source in Kenya and provides $69 \%$ of the Country's overall energy requirements, petroleum and electricity accounting for about $22 \%$ and $9 \%$ respectively. About $55 \%$ of this is from farmlands as woody biomass, crop residue, and animal waste, and the remaining 45\% is from forests [1]. A national household budget survey [2] carried out from September 2015 to August 2016 showed that most households use this biomass as fuel. In the 11.4 million households surveyed, the primary source of cooking fuel was firewood (54.6\%), charcoal (14.6\%), kerosene (14\%), and liquefied petroleum gas (LPG) (13.4\%). In the urban areas, households mainly used kerosene (29\%), LPG (27.6), charcoal (21.9\%), and firewood (16.1\%). A study done in 2018 showed that Kenyan households using LPG as their primary cooking option also use one or more traditional fuels like charcoal (47\%), wood (17\%), and kerosene (18\%) [3].

Arid and semi-arid lands (ASALs) cover more than $80 \%$ of the land and are a major source of woodfuel. However, the woodfuel is extracted in an uncontrolled and unmanaged manner, with natural regeneration as the way of recovery $[4,5]$. To mitigate climate change, and provide sustainable energy for all, Kenya has developed policies to promote a transition to clean cooking fuels. These include promoting LPG and ethanol in urban areas, clean biomass cookstoves in rural areas, and alternative fuels such as compressed biomass and biogas [6, 1]. There is also recent legislation [7] that seeks to promote efficient and sustainable production (e.g. growing fast-maturing trees for energy production and biofuels), distribution, and marketing of biomass energy resources.

There is a growing demand for charcoal in Kenya caused mainly by population growth and urbanization, and about 2.5 million tonnes are produced annually [8]. Several advantages make charcoal as a fuel attractive for cooking compared to un-carbonized biomass. Its calorific value is roughly double that of un-carbonized material (its higher heating value per unit mass is approximately $30 \mathrm{MJ} / \mathrm{kg}$ with $5 \%$ moisture content compared to approximately $15 \mathrm{MJ} / \mathrm{kg}$ of firewood with $15 \%$ moisture content). Charcoal can be stored for long periods because it cannot get damaged by rain or moisture, it is available in the local market in small quantities, and it can be burned in inexpensive stoves [9]. The cost per $\mathrm{kg}$ (and per megajoule) of LPG, charcoal, and wood pellets is about US\$1.50 (US\$0.03), US\$ 0.47 (US\$0.02), and US\$ 0.38 (US\$ 0.02) respectively [3, 10-12].

The artisanal Kenya ceramic jiko (KCJ) cookstove, developed in 1984, has been widely accepted. $34 \%$ of all households in Kenya own it (40\% urban and $31 \%$ rural), and about 343,000 units are sold each year with an annual market value of US\$1.3 million. Households that use charcoal primarily use approximately $395 \mathrm{~kg}$ of charcoal per year [3]. The thermal efficiency of KCJ and similar stoves is below 27\% [13, 14]. Factory-assembled modern charcoal cookstoves e.g. Jikokoa, JikoFresh, and SuperSaver, are increasingly being introduced [3].

The most widely used method for converting wood to charcoal in Kenya is the earth-mound and pit kilns with 10-14\% wood-to-charcoal conversion efficiency. Although kilns with efficiencies of up to $30 \%$ have been promoted, e.g. improved earth Kiln, Casamance, and Brazillian masonry (or "beehive") kiln, their actual use in charcoal production is very minimal [8]. The conversion of $1 \mathrm{~kg}$ of wood, therefore, yields only $0.1-0.3 \mathrm{~kg}$ of charcoal. In other words, to produce $1 \mathrm{~kg}$ of charcoal with a specific energy content of $30 \mathrm{MJ} / \mathrm{kg}, 3.3-10 \mathrm{~kg}$ of firewood is required, which would otherwise have a total energy content of $53-160 \mathrm{MJ}[9,15]$. 
To save the energy currently being lost when converting wood to charcoal, technologies e.g top-lit-up-draft (TLUD) gasifier cookstoves, that provide clean cooking energy from biomass pellets at thermal efficiencies greater than $50 \%[16,17]$ are available. Compared with the direct combustion of solid biomass, gasifier cookstoves have higher thermal efficiency and fewer pollutant emissions since the syngas created from solid biomass is easily mixed with air to generate heat [18].

To densify lignocellulosic biomass, the first machine in the process line is a chipper. The wood chips are dried to about $10 \%$ (wet basis) in a rotary drum dryer that can use woodfuel. After drying, hammer mills are used to grind the chips to a screen size of 3.2 to $6.4 \mathrm{~mm}$, a particle size suitable for pelleting. The ground biomass is then compacted using a ring or flat die pelletizer. Pellet density ranges from 1000 to 1200 $\mathrm{kg} / \mathrm{m}^{3}$. Pellets are then sifted over a screen to remove fines and weighed before storage $[19,20]$. Various factors that affect the economic viability of pellet production have been studied [21-23].

Pellets production in Kenya is still in its nascent stages. To promote pellets as a cooking fuel, SNV and EcoZoom undertook pilot studies in 2014 - 2015, aiming at increasing access and use of pellet stoves in urban and peri-urban markets. Pellets were tested on both locally manufactured gasifier stoves (WISDOM and SCODE) and imported ones (Philips and TERI). A key challenge observed in the adoption of pellet-cookstoves was the high upfront cost of the stoves (e.g. a WISDOM gasifier stove costed US\$34) [3]. Other factors also affect the adoption of pellet gasifier cookstoves, and households will generally adopt a fuel stacking model [24-30, 12]. Ongoing pellet production and gasifier cookstoves initiatives in Kenya include: Lean Energy Solutions Ltd., Iko Briq Ltd., Power Spot Ltd., Wisdom Innovations Ltd., and KIRDI $[3,10,31,32]$.

This study compared the energy efficiency and emissions of a natural-draft gasifier cookstove using wood pellets to contemporary charcoal cookstoves in Kenya.

\subsection{Limitations of the study}

Field tests to determine performance of cookstoves in kitchens were not conducted.

It was beyond the scope of the study to determine to what extent the targeted communities would adopt the pellet cookstoves if promoted. Adoption of cookstoves is dependent on many factors, including availability and affordability of high-quality cookstoves, reliability and accessibility of fuel supply, safety and usefulness of the cookstove in application, technical/industrial support for stove manufacturers, innovative funding mechanisms for consumers, awareness, and post-sales interventions, and multi-stakeholder collaboration [25-30].

A few firms are already manufacturing biomass briquettes and pellets in Kenya from industrial wastes like sugarcane bagasse and sawdust, although at a small scale $[3,10]$. However, we did not investigate their experiences, especially regarding biomass availability, cost of investment, operation and maintenance, location and plant capacity, logistics, and energy costs [20, 21].

\section{Materials And Methods}

\subsection{Cookstoves tested}

We tested the three cookstoves shown in Fig. 1. The natural-draft gasifier cookstove (Gastov206) was fabricated at Kenya Industrial Research and Development Institute (KIRDI). Its weight was $9.46 \mathrm{~kg}$, height $37 \mathrm{~cm}$, and diameter $24 \mathrm{~cm}$. The main features, illustrated in Fig. 2, were:

- A metal casing insulated with Rockwool and fireclay insulation;

- removable stainless steel fuel canister, of diameter $13 \mathrm{~cm}$ and depth $21 \mathrm{~cm}$, in which the pellets were placed;

- removable fuel platform of height $11.5 \mathrm{~cm}$, placed inside the fuel canister;

- a removable nozzle on the burner that ensures mixing of combustible gases and heated secondary air;

- damper used to control primary airflow;

- fuel canister handler; and

- snuffer for extinguishing the fuel in the fuel canister.

We obtained the charcoal cookstoves, a modern charcoal jiko (MCJ), and Kenya ceramic jiko (KCJ), from distributors in Nairobi. The outer body of the MCJ was made from mild steel and ceramic wool. It weighed $3.88 \mathrm{~kg}$ and had a height of $25 \mathrm{~cm}$. Its top diameter was $26 \mathrm{~cm}$. The fuel chamber, made of alloy steel, had a diameter of $13.5 \mathrm{~cm}$ and a depth of $8 \mathrm{~cm}$.

The metal cladding of the KCJ was made from mild steel sheets that held a ceramic fuel chamber (liner). It weighed $3.70 \mathrm{~kg}$ and had a height of $20 \mathrm{~cm}$. The top-diameter was $28 \mathrm{~cm}$. Its ceramic fuel chamber had a diameter of $21.5-16 \mathrm{~cm}$, a depth of $8 \mathrm{~cm}$, and had 14 holes. 
Fig. 1 Gastov206, MCJ and KCJ test cookstoves

Fig. 2 Exploded view of the main components of Gastov206

\subsection{Cookstove Test Method}

We used ISO 19867-1 laboratory testing method [33] to determine the cookstoves' thermal efficiency (\%), fire-power (kW), cooking-power (kW), emission of carbon monoxide $\left(\mathrm{g} / \mathrm{MJ}_{\mathrm{d}}\right.$ and $\mathrm{g} / \mathrm{min}$ of $\left.\mathrm{CO}\right)$, and emission of particulate matter less than $2.5 \mu \mathrm{m}(\mathrm{mg} / \mathrm{MJ}$ and $\mathrm{mg} / \mathrm{min}$ of PM2.5). The Appendix shows how we computed these performance parameters.

Table 1 and Fig. 3 show the laboratory conditions and equipment that we used [34]. Five liters of water were heated on the cookstoves for 30 min at both high and medium power levels. There were five replicates for each power level. We did all tests under the hood of the Laboratory Emissions Measurement System (LEMS). We used one Whatman GF/C filter for PM2.5 gravimetric measurements during an entire test that consisted of a high power (cold start) phase, and medium power (hot start) phase, each 30 min long. The LEMS acquired real-time data and saved it as MS Excel CSV files.

Table 1: Test conditions

\begin{tabular}{|c|c|}
\hline $\begin{array}{l}\text { Test dates } \\
\text { and lab. } \\
\text { location }\end{array}$ & Sept 10, 2019 to Sept 30, 2019, Nairobi, Kenya \\
\hline Altitude & $1655 \mathrm{~m}$ \\
\hline $\begin{array}{l}\text { Air } \\
\text { temperature }\end{array}$ & $18-21^{\circ} \mathrm{C}$ \\
\hline Humidity & $50-70 \%$ \\
\hline $\begin{array}{l}\text { Wind } \\
\text { condition }\end{array}$ & No wind \\
\hline \multirow{4}{*}{$\begin{array}{l}\text { Laboratory } \\
\text { Emissions } \\
\text { Measurement } \\
\text { System } \\
\text { (LEMS) } \\
\text { components }\end{array}$} & $\begin{array}{l}\text { The emissions collection hood had a } 15.2 \mathrm{~cm} \text { ducting connected to an exhaust blower (open flow rate of } 1200 \text { cubic } \\
\text { feet per minute). Dilution valves were adjusted to provide a differential pressure of } 1.07 \mathrm{~cm} \mathrm{H}_{2} 0 \text { (i.e. a gas flow of } 550\end{array}$ \\
\hline & $\begin{array}{l}\mathrm{m}^{3} / \mathrm{hr} \text { ). K-type thermocouple measured exhaust gas temperature. An amplified pitot tube measured flow grid pressure } \\
\text { drop within ducting for calculation of mass flow rate of gases in ducting. Gas samples were collected, at a flow rate of } \\
4.4 \mathrm{~L} / \mathrm{min} \text {, from the ducting by sampling tubes connected to a sensor box fitted with a suction pump. In the sensor box, } \\
\text { the exhaust gas sampled passed through a PM (light scattering photometer) sensor, CO (electrochemical) sensor, and } \\
\mathrm{CO}_{2} \text { (NDIR) sensor before exiting the box. Water temperature was measured by a bead probe thermocouple ( }-4 \text { to } 260\end{array}$ \\
\hline & $\left.\left.{ }^{\circ} \mathrm{C}\right)\right)$. The sensor box had a real time data acquisition system. \\
\hline & $\begin{array}{l}\text { The PM2.5 gravimetric system consisted of tubing connected to hood ducting, vacuum pump (16.7 L/min), PM2.5 } \\
\text { cyclone separator, filter housing for Whatman GF/C - glass fiber filters, and an analytical balance (0.01 mg resolution). }\end{array}$ \\
\hline $\begin{array}{l}\text { Other } \\
\text { equipment } \\
\text { used }\end{array}$ & $30 \mathrm{~kg}$ capacity weighing scale, bomb calorimeter, drying oven and 2 desiccators \\
\hline $\begin{array}{l}\text { Pot used (no } \\
\text { lid) }\end{array}$ & aluminum, height $23 \mathrm{~cm}$, diameter $12.5 \mathrm{~cm}$, weight $401 \mathrm{~g}$, \\
\hline
\end{tabular}

Fig. 3 Set-up of test equipment

\subsection{Fuels used}

We obtained pellets having a diameter of $6 \mathrm{~mm}$ (size 6 pellets) from lko Briq Ltd., and those having a diameter of $8 \mathrm{~mm}$ (size 8 pellets) from EcoZoom. The pellets were made from sawdust, an industrial waste product. Prosopis juliflora charcoal was from a vendor in Nairobi. We used standard laboratory methods to determine the fuels' calorific value (ASTM D5865), moisture content (ASTM D3302), ash content (ASTM D3174), bulk density, and size.

We used $600 \mathrm{~g}$ of pellets as fuel to test Gastov206. To light the cookstove, we soaked $120 \mathrm{~g}$ of pellets with $30 \mathrm{~g}$ of bioethanol in a beaker. The soaked pellets were placed on top of the other pellets in the fuel canister and ignited using a match stick.

For MCJ and KCJ, we used $370 \mathrm{~g}$ and $409 \mathrm{~g}$ respectively of charcoal fuel. A few charcoal pieces, soaked with 20 - $22 \mathrm{~g}$ of kerosene in a beaker, were placed in the middle of the charcoal fuel and ignited. 
To operate the cookstoves at 'high power', we allowed maximum entry of primary under-grate air. To test at 'medium power', we reduced by half the primary air entry by adjusting the damper of Gastov206, the ashtray of MCJ, and the door of KCJ.

The pellet fuel and pellet char remaining after testing Gastov206 were weighed after removing the nozzle from the burner and lifting the fuel canister using a handler. We used a snuffer to suffocate the remaining pellets until they had cooled enough for separating the unburnt and carbonized portions. To determine the weight of the charcoal remaining after testing charcoal stoves, we weighed the cookstove together with the remaining charcoal and deducted the initial weight of the empty cookstove.

\subsection{Experimental design}

There were four independent variables: Gastov206 using size 6 pellets, Gastov206 using size 8 pellets, MCJ using charcoal, and KCJ using charcoal. The dependent variables were five: thermal efficiency (\%), fire-power (kW), cooking-power (kW), emission of carbon monoxide $\left(\mathrm{g} / \mathrm{MJ}_{\mathrm{d}}\right.$ and $\mathrm{g} / \mathrm{min}$ of $\left.\mathrm{CO}\right)$, and emission of particulate matter less than $2.5 \mu \mathrm{m}\left(\mathrm{mg} / \mathrm{MJ}_{\mathrm{d}}\right.$ and $\mathrm{mg} / \mathrm{min}$ of PM2.5. The Appendix shows how we computed the performance parameters.

We carried out Analysis of variance (ANOVA) and Tukey Honestly Significant Difference (HSD) tests at a 95\% level of confidence [35]. We used the Tukey HSD test to group means that had no significant differences. We were then able to determine significant differences in performance between Gastov206 using pellets and charcoal cookstoves, and between Gastov206 using size 6 pellets and size 8 pellets.

\section{Results And Discussion}

\subsection{Fuel characteristics}

Table 2 shows the properties of fuels used to test the cookstoves. Compared to size 6 pellets, size 8 pellets had higher calorific value, lower ash content, lower moisture content, and lower bulk density. These results compare well with Gorzelanya et al. [36], who showed that pellets of diameter $6 \mathrm{~mm}$ and $8 \mathrm{~mm}$ from coniferous and deciduous sawdust had moisture content of $6.8-7.5 \%$, ash content of $0.3-0.6 \%$, and calorific value of $17.7-19.2 \mathrm{MJ} / \mathrm{kg}$. Oduor and Githiomi [37] showed that Prosorpis juliflora charcoal had calorific value, moisture content and ash content of $32,861 \mathrm{~kJ} / \mathrm{kg}, 4.6 \%$ and $2.3 \%$ respectively.

In addition to industrial wastes, there is a potential of manufacturing pellets from rotational woodlots in ASALs [38], plantation forestry [39], and $\mathrm{C}_{4}$ energy crops [40-42].

Table 2: Properties of fuels used to test cookstoves

\begin{tabular}{|llllll|}
\hline Fuel & calorific value $(\mathrm{kJ} / \mathrm{kg})$ & Moisture content $(\%)$ & Ash content $(\%)$ & Bulk density $\left(\mathrm{kg} / \mathrm{m}^{3}\right)$ & Average Dimensions $(\mathrm{mm})$ \\
\hline Size 6 pellets & $18,416 \pm 774$ & $8.0 \pm 0.1$ & $0.96 \pm 0.03$ & $640 \pm 5$ & $28.9 \pm 7$ \\
\hline Size 8 pellets & $19,581 \pm 1221$ & $7.4 \pm 0.2$ & $0.39 \pm 0.04$ & $600 \pm 7$ & $19.4 \pm 8$ \\
\hline Charcoal & $31,706 \pm 1122$ & $4.6 \pm 0.1$ & $3.2 \pm 0.3$ & $290 \pm 4$ & $41 \times 24 \times 66$ \\
\hline
\end{tabular}

\subsection{Fuel consumption}

During the 30 min test (average of high and medium power tests), Gastov206 consumed $359 \pm 18 \mathrm{~g}$ of size 6 pellets and $363 \pm 35 \mathrm{~g}$ of size 8 pellets. Char remaining was $97 \pm 4 \mathrm{~g}$ (size 6) and $81 \pm 6 \mathrm{~g}$ (size 8). MCJ and KCJ consumed an average of $174 \pm 18 \mathrm{~g}$ and $171 \pm 13 \mathrm{~g}$ of charcoal respectively.

Gastov206 consumed pellets at a rate of $12 \mathrm{~g} / \mathrm{min}$, and char formed at a rate of $3 \mathrm{~g} / \mathrm{min}$, a pellet-to-char conversion ratio of $25 \%$. Therefore, approximately $50 \mathrm{~min}$ is required to turn the $600 \mathrm{~g}$ of pellets into $150 \mathrm{~g}$ of charcoal. When $600 \mathrm{~g}$ of size 6 pellets were allowed to burn longer than the 30 min test, Gastov206 'switched' from gasifying pellets to burning charcoal with a flame after approximately 57 min. The charcoal kept the water temperature above $85.5^{\circ} \mathrm{C}$ for a further $30 \mathrm{~min}$ as the charcoal slowly turned to ash. Therefore, Gastov206 using $600 \mathrm{~g}$ of pellets can provide cooking power for more than 1.5 hours.

Gastov206 having a batch of $600 \mathrm{~g}$ of pellets, can therefore be 'stacked' with an LPG cookstove to cook meals like boiling a mixture of maize and beans, a common meal in Kenya. In urban areas, Ochieng et al. [43] showed that fuel stacking of LPG with charcoal was the norm to overcome the supply, cost, and practical challenges of relying on LPG. Using LPG to boil a mixture of maize and beans was considered impractical. 
The cookstoves performed as shown in Table 3. ANOVA and Tukey HSD test (Table 4) showed that there were significant differences $(p<$ 0.05) between Gastov206 using pellets and charcoal stoves in all performance variables except for PM2.5 ( $\mathrm{mg} / \mathrm{MJ}_{\mathrm{d}}$ and $\mathrm{mg} / \mathrm{min}$ ) emission.

On average, when using both size 6 and size 8 pellets, the thermal efficiency of Gastov206 were significantly higher compared to charcoal cookstoves. This shows that more energy in the fuel is lost by charcoal cookstoves $(69 \%)$, compared to pellet gasifier cookstoves $(31 \%)$, during cooking operations.

Gastov206 using size 6 pellets showed a thermal efficiency higher than that reported for forced-draft pellet gasifier cookstoves [44, 13]. Jetter et al. [13] showed a natural-draft pellet gasifier cookstove (StoveTec TLUD) had a higher overall thermal efficiency of $53 \%$, compared to a forced-draft pellet gasifier cookstove (Oorja stove) that had 32\%. Still, Bentson, and Li [45] showed a natural draft TLUD pellet cookstove (ND TLUD 4) had a thermal efficiency greater than $50 \%$, higher than that of forced-draft TLUD cookstoves.

As shown by Fig. 4, Gastov206 showed significantly higher fire-power and cooking-power using size 8 pellets compared with size 6 pellets. Size 8 pellets took approximately 26 min to boil 5 liters of water during the 'cold start' high power phase, the quickest compared to all the other cookstoves. The significantly higher fire-power of Size 8 pellets, compared to size 6 pellets, can be attributed to their higher calorific value, lower bulk density, lower moisture content, and lower ash content, which caused a higher combustion reactivity and burn rate.

Although charcoal cookstoves had the highest fire-power, they showed the lowest cooking-power because of their low thermal efficiencies (Fig. 4). We observed that the charcoal cookstoves could not boil 5 litres of water (in a pot without a lid) within 30 min. Studies have shown that KCJ (known as Gyapa in Ghana) and other modern charcoal cookstoves, take 30 - 60 min to boil 5 litres of water [14, 13].

As shown by Table 4 and Fig. 5, compared to Gastov206, the charcoal cookstoves had significantly higher CO emission. Emission of PM2.5 from Gastov206 was higher compared to charcoal cookstoves. However, the difference was not significant $(p>0.05)$. Emissions of $\mathrm{CO}$ and $\mathrm{CO}_{2}$ from charcoal cookstoves increased with time, as burning rate of charcoal increased (Fig. 6).

The natural-draft Gastov206 has high PM2.5 and CO emissions compared to Mimimoto, a forced-draft TLUD gasfier cookstove, reported to have PM2.5 and $\mathrm{CO}$ emissions of $13.94 \mathrm{mg} / \mathrm{MJ}_{\mathrm{d}}$ and $0.154 \mathrm{~g} / \mathrm{MJ}_{\mathrm{d}}$ respectively [44]. Air supply to force draft TLUD gasifiers is by axial fans powered by electricity to favor a good mixture between producer gas and secondary air in the combustion zone $[17,46,47]$.

Table 3: Cookstoves performance results

\begin{tabular}{|c|c|c|c|c|}
\hline \multirow[t]{2}{*}{ Performance variable } & \multicolumn{2}{|c|}{ Gastov 206 with Pellets } & \multicolumn{2}{|l|}{ Charcoal } \\
\hline & Size 6 pellets & Size 8 pellets & MCJ & KCJ \\
\hline Thermal efficiency (\%) & $73 \pm 7$ & $65 \pm 8$ & $35 \pm 8$ & $27 \pm 6$ \\
\hline Fire-power (kW) & $1.41 \pm 0.15$ & $1.87 \pm 0.31$ & $2.79 \pm 0.45$ & $2.61 \pm 0.39$ \\
\hline Cooking-power (kW) & $0.95 \pm 0.05$ & $1.13 \pm 0.07$ & $0.89 \pm 0.18$ & $0.68 \pm 0.22$ \\
\hline PM2.5 mass per useful energy delivered $\left(\mathrm{mg} / \mathrm{MJ}_{\mathrm{d}}\right)$ & $52.35 \pm 33.12$ & $61.5 \pm 48.47$ & $40.81 \pm 32.03$ & $41.13 \pm 19.07$ \\
\hline $\mathrm{CO}$ mass per useful energy delivered $\left(\mathrm{g} / \mathrm{MJ}_{\mathrm{d}}\right)$ & $4.46 \pm 0.92$ & $5.47 \pm 1.31$ & $24.36 \pm 10.69$ & $20.82 \pm 4.36$ \\
\hline PM2.5 mass per time $(\mathrm{mg} / \mathrm{min})$ & $3.21 \pm 2.03$ & $4.37 \pm 3.44$ & $2.35 \pm 2.04$ & $1.69 \pm 0.76$ \\
\hline CO mass per time $(\mathrm{g} / \mathrm{min})$ & $0.27 \pm 0.06$ & $0.39 \pm 0.10$ & $1.35 \pm 0.52$ & $0.89 \pm 0.27$ \\
\hline
\end{tabular}

Table 4: Tukey Honestly Significant Difference (HSD) test results 


\begin{tabular}{|c|c|c|c|c|c|}
\hline \multirow[t]{2}{*}{ Performance Variable } & \multirow[t]{2}{*}{ Cookstove type } & \multirow[t]{2}{*}{$\mathrm{N}$} & \multicolumn{3}{|c|}{ Comparison of means ${ }^{a}($ alpha $=0.05)$} \\
\hline & & & 1 & 2 & 3 \\
\hline \multirow[t]{5}{*}{ Thermal efficiency (\%) } & KCJ & 10 & 27.30 & & \\
\hline & MCJ & 10 & 34.80 & & \\
\hline & Gastov 206 with size 8 pellets & 10 & 65.30 & & \\
\hline & Gastov 206 with size 6 pellets & 10 & 72.60 & & \\
\hline & Sig. & 0.108 & 0.123 & & \\
\hline \multirow[t]{5}{*}{ Fire-power (kW) } & Gastov 206 with size 6 pellets & 10 & 1.4130 & & \\
\hline & Gastov 206 with size 8 pellets & 10 & 1.8740 & & \\
\hline & KCJ & 10 & 2.6120 & & \\
\hline & MCJ & 10 & 2.7870 & & \\
\hline & Sig. & 1.000 & 1.000 & 0.665 & \\
\hline \multirow[t]{5}{*}{ Cooking-power (kW) } & KCJ & 10 & 0.6803 & & \\
\hline & MCJ & 10 & 0.8926 & & \\
\hline & Gastov 206 with size 6 pellets & 10 & 0.9511 & 0.9511 & \\
\hline & Gastov 206 with size 8 pellets & 10 & 1.1307 & & \\
\hline & Sig. & 1.000 & 0.817 & 0.050 & \\
\hline \multirow[t]{5}{*}{ CO mass per useful energy delivered $\left(\mathrm{g} / \mathrm{MJ}_{\mathrm{d}}\right)$} & Gastov 206 with size 6 pellets & 10 & 4.4560 & & \\
\hline & Gastov 206 with size 8 pellets & 10 & 5.4720 & & \\
\hline & KCJ & 10 & 20.8180 & & \\
\hline & MCJ & 10 & 24.3550 & & \\
\hline & Sig. & 0.980 & 0.534 & & \\
\hline \multirow[t]{5}{*}{$\mathrm{CO}$ mass per useful energy delivered $(\mathrm{g} / \mathrm{min})$} & Gastov 206 with size 6 pellets & 10 & 0.2720 & & \\
\hline & Gastov 206 with size 8 pellets & 10 & 0.3940 & & \\
\hline & $\mathrm{KCJ}$ & 10 & 0.8860 & & \\
\hline & MCJ & 10 & 1.3470 & & \\
\hline & Sig. & 0.812 & 1.000 & 1.000 & \\
\hline \multirow[t]{5}{*}{ PM2.5 mass per time (mg/min) } & $\mathrm{KCJ}$ & 10 & 1.6880 & & \\
\hline & MCJ & 10 & 2.3500 & & \\
\hline & Gastov 206 with size 6 pellets & 10 & 3.2050 & & \\
\hline & Gastov 206 with size 8 pellets & 10 & 4.3720 & & \\
\hline & Sig. & 0.057 & & & \\
\hline
\end{tabular}

a The Tukey HSD test checks pairs of means of all independent variables using the HSD statistic ( ). If $q>$, the two means are significantly different and are not grouped together (not homogeneous). This enables pairwise comparisons ([35]).

\section{Conclusion}

Gastov206 using pellets is more energy-efficient compared to KCJ and MCJ charcoal cookstoves. More energy in the fuel was lost by charcoal cookstoves, compared to pellet gasifier cookstoves, during the test. Although the emission of CO was significantly lower in Gastov206, further 
improvements are needed to reduce PM2.5 emissions. Controlled cooking and kitchen performance tests can provide actual fuel usage when cooking typical foods.

The gasifier cookstove can make charcoal from biomass during cooking, at a pellet-to-char ratio of $25 \%$. This ratio is higher than the wood-tocharcoal conversion ratios of earth-mound and pit kilns widely used in Kenya. This charcoal, when left to burn in the cookstove, provides additional fuel for cooking. Therefore, using pellet gasifier cookstoves instead of charcoal cookstoves, energy in the original biomass will not be lost during charcoal burning.

Considering that wood-to-charcoal conversion efficiencies are low and charcoal cookstoves have low thermal efficiencies, a substantial amount of energy can be saved by switching from charcoal to using pellets. We recommend kitchen trials to investigate actual fuel usage, user acceptance, and fuel stacking models that communities can adopt with the pellet cookstove. For example, the pellet gasifier cookstove can be used for operations like heating water and cooking local foods requiring high cooking-power (e.g. boiling maize and bean grains). Fossil fuels, e.g. LPG, can be used sparingly to cook vegetables and other dishes requiring low cooking-power.

Wood pellets of diameter $6 \mathrm{~mm}$ and $8 \mathrm{~mm}$, or a mixture of both, can be used with natural-draft gasifier cookstoves. However, the larger pellets (diameter $8 \mathrm{~mm}$ ) provided higher fire-power because they had a higher calorific value, lower moisture content, and lower ash content. The lower bulk density caused more air spaces within the pellets, leading to more airflow and a higher burning rate.

The pellets used in this study were made from sawdust, an industrial waste product. To increase adoption of pellet cookstoves, we recommend further multi-stakeholder collaborative research to examine the potential of a sustainable wood pellet supply chain in Kenya and solutions to the other barriers that hinder the widespread adoption of efficient cookstoves.

\section{Declarations}

Funding: Research support (including salaries, equipment, supplies, and other expenses) was provided by Kenya Industrial Research and Development Institute.

Conflicts of interest/Competing interest. The authors are employees of Kenya Industrial Research and Development Institute

Availability of data and material: Raw data and materials used are available

Code availability: Not applicable

\section{Abbreviations}

Top-lit up-draft (TLUD), carbon monoxide (CO), particulate matter less than $2.5 \mu \mathrm{m}$ (PM2.5), mega joule delivered to water in cooking pot $\left(\mathrm{MJ}_{\mathrm{d}}\right)$, modern charcoal jiko (MCJ) and Kenya ceramic jiko (KCJ)

\section{References}

1. Ministry of Energy (2018) National energy policy. Republic of Kenya. https://kplc.co.ke/img/full/BL4PdOqKtxFT_National\%20Energy\%20Policy\%200ctober\%20\%202018.pdf. Accessed 25 October 2019

2. Kenya National Bureau of Statistics (2018) 2015/16 Kenya integrated household budget survey - Basic report. http://statistics.knbs.or.ke/nada/index.php/catalog/88/download/745 Accessed 11 June 2020

3. Ministry of Energy and Clean Cooking Association of Kenya (2019) Kenya cooking sector study: Assessment of the supply and demand of cooking solutions at the household level. EED Advisory. https://eedadvisory.com/wp-content/uploads/2020/09/MoE-2019-KenyaCooking-Sector-Study-compressed.pdf Accessed 11 June 2020

4. FAO (2017) The charcoal transition: Greening the charcoal value chain to mitigate climate change and improve local livelihoods. Rome. http://www.fao.org/3/a-i6935e.pdf. Accessed 25 October 2019

5. Njenga M, Karanja N, Munster C, liyama M, Neufeldt H, Kithinji J, Jamnadass R (2013) Charcoal production and Strategies to enhance its sustainability in Kenya. Development in Practice 23(3):359-371. doi:10.1080/09614524.2013.780529

6. Ministry of Environment and Forestry (2018) National climate change action plan (Kenya) 2018-2022. Government of Kenya. http://www.environment.go.ke/wp-content/uploads/2020/03/NCCAP-2018-2022-v2.pdf Accessed 25 October 2019

7. Republic of Kenya (2019) Energy act, No. 1 of 2019. Kenya Gazette Supplement No. 29 (Acts No. 1). http://kenyalaw.org/kl/fileadmin/pdfdownloads/Acts/2019/EnergyAct_No.1of2019.PDF Accessed 25 October 2019

Page 8/13 
8. Ministry of Environment, Water and Natural Resources (2013) Analysis of the charcoal value chain in Kenya. Government of Kenya. http://www.kenyaforestservice.org/documents/redd/Charcoal\%20Value\%20Chain\%20Analysis.pdf. Accessed 25 October 2019

9. Lohri CR, Rajabu HM, Sweeney DJ, Zurbrugg C (2016) Char fuel production in developing countries - A Review of urban biowaste carbonization. Renewable and Sustainable Energy Reviews 59:1514-1530. doi: 10.1016/j.rser.2016.01.088

10. Iko Briq Ltd. (2019) IKO pellets (10Kg) Pack. https://shop.ikobriq.com/product/iko_pellets/Accessed $11^{\text {th }}$ June 2020

11. Koko Networks (2020) Koko Fuel. https://kokofuel.com/koko-fuel/ Accessed 11 June 2020

12. Global Alliance for Clean Cookstoves (2016) Comparative analysis of fuels for cooking: Life cycle environmental impacts and economic and social considerations. https://www.cleancookingalliance.org/assets-facit/Comparative-Analysis-for-Fuels-FullReport.pdf Accessed 25 October 2019

13. Jetter J, Zhao Y, Smith KR, Khan B, Yelverton Y, De Carlo P, Hays MD (2012) Pollutant emissions and energy efficiency under controlled conditions for household biomass cookstoves and implications for metrics useful in setting international test standards. Environ. Sci. Technol. 46:10827-10834. doi: 10.1021/es301693f

14. Boafo-Mensah G, Ampomah-Benefo K, Animpong MAB, Oduro WO, Kotey EN, Akufo-Kumi K, Laryea GN (2013) Thermal efficiency of charcoal fired cookstoves in Ghana. Global Advanced Research Journal of Engineering, Technology and Innovation 2(3):102-110.

15. GIZ (2014) Multiple-household fuel use - a balanced choice between firewood, charcoal and LPG. https://cleancookstoves.org/binarydata/RESOURCE/file/000/000/287-1.pdf. Accessed 25 October 2019

16. Tryner J, Willson BD, Marchese AJ (2014) The effects of fuel type and stove design on emissions and efficiency of natural-draft gasifier biomass cookstoves. Energy for Sustainable Development 23:99-109.

17. Champion WM, Grieshop AP (2019) Pellet-fed gasifier stoves approach gas-stove like performance during in-home Use in Rwanda. Environ. Sci. Technol. 53(11):6570-6579. doi: 10.1021/acs.est.9b00009

18. Gumino B, Pohlman NA, Barnes J, Wever P (2020) Design features and performance evaluation of natural-draft, continuous operation gasifier cookstove. Clean Technologies 2(3):252-269. https://doi.org/10.3390/cleantechnol2030017

19. Protic M, Mitic D, Stefanovic V(2011) Wood pellets production technology. Safety Engineering, UDC, 303.211:614.256. doi: 10.7562/SE2011.1.01.05

20. Pantaleo A, Villarini M, Colantoni A, Carlini M, Santoro F, Hamedani SR (2020) Techno-economic modeling of biomass pellet routes: Feasibility in Italy. Energies 13:1636. doi:10.3390/en13071636

21. Carter E, Shan M, Zhong Y, Ding W, Zhang Y, Baumgartner J, Yang X (2018) Development of renewable, densified biomass for household energy in China. Energy for Sustainable Development 46:42-52. https://doi.org/10.1016/j.esd.2018.06.004

22. Mani S, Sokhansanj S, Turhollow A (2006) Economics of producing fuel pellets from biomass. Applied Engineering in Agriculture 22(3):421-426

23. Reed D, Bergman R, Kim J, Taylor A, Harper D, Jones D, Knowles C, Puettmann ME (2012) Cradle-to-gate life-cycle inventory and impact assessment of wood fuel pellet manufacturing from hardwood flooring residues in the Southeastern United States. Forest Products Journal 62(4): 280-288. https://doi.org/10.13073/FPJ-D-12-00015.1

24. Bailis R, Ghosh E, O’Connor M, Kwamboka E, Ran Y, Lambe F (2020) Enhancing clean cooking options in peri-urban Kenya: a pilot study of advanced gasifier stove adoption. Environmental Research Letters 15:084017. https://doi.org/10.1088/1748-9326/ab865a

25. Kara A, Zerriffi H (2018) From cookstove acquisition to cooking transition: Framing the behavioural aspects of cookstove interventions. Energy Research \& Social Science 42:23-33. https://doi.org/10.1016/j.erss.2018.02.015

26. International Bank for Reconstruction and Development (2015) The state of the global clean and improved cooking sector. ESMAP Technical Report 007/15.

http://www.esmap.org/sites/esmap.org/files/DocumentLibrary/ESMAP_State_of_Globa_Clean_Improved_Cooking_sector_Optimized.pdf. Accessed 25 October 2019

27. Karanja A, Mburu F, Gasparatos A (2019) A multi-stakeholder perception analysis about the adoption, impacts and priority areas in the Kenyan clean cooking sector. Sustainability Science 13:333-351. DOI 10.1007/s11625-019-00742-4

28. Karanja A, Gasparatos A (2020) Adoption and impacts of clean bioenergy cookstoves in Kenya. Renewable and Sustainable Energy Reviews 102:285-306. https://doi.org/10.1016/j.rser.2018.12.006

29. Seguin R, Flax VL, Jagger $P$ (2018) Barriers and facilitators to adoption and use of fuel pellets and improved cookstoves in urban Rwanda. PLoS ONE 13(10): e0203775. https://doi.org/10.1371/journal.pone.0203775

30. Gitau JK, Mutune J, Sundberg C, Mendum R, Njenga M (2019) Factors influencing the adoption of biochar-producing gasifier cookstoves by households in rural Kenya. Energy for Sustainable Development 52:63-71. https://doi.org/10.1016/j.esd.2019.07.006 
31. Gituku B, Kamau J, Mwitari P (2017) Energy potential and efficiency of a TLUD gasifier cookstove utilizing bagasse briquettes. Journal of Applied Science, Engineering and Technology for Development 2:2. https://jasetd.dkut.ac.ke/site/volume22 Accessed 25 October 2019

32. Gitau JK, Sundberg C, Mendum R, Mutane J, Njenga M (2019) Use of biochar-producing gasifier cookstove improves energy use efficiency and indoor air quality in rural households. Energies 12:4285. doi:10.3390/en12224285

33. International Organization for Standardization (2018) ISO 19867-1:2018 Clean cookstoves and clean cooking solutions - Harmonized laboratory test protocols - Part 1: Standard test Sequence for emissions and performance, safety and durability.

34. Aprovecho Research Center (2013) Instructions for use of the laboratory emissions monitoring system (LEMS). Oregon, USA.

35. Lane DM, Scott D, Hebl M, Guerra R, Osherson D, Zimmer H (2003) Introduction to statistics. Open Textbook Library. http://onlinestatbook.com/Online_Statistics_Education.pdf Accessed 11 June 2020

36. Gorzelanya J, Zardzewiały M, Murawski, Matłok N (2020) Analysis of selected quality features of wood pellets. Agricultural Engineering 24(1):25-34

37. Oduor NM, Githiomi JK (2013) Fuel-wood energy properties of Prosopis juliflora and Prosopis pallida grown in Baringo District, Kenya. African Journal of Agricultural Research 8(21):2476-2481.

38. Liyama M, Neufeldt H, Dobie P, Njenga M, Ndegwa G, Jamnadass R (2014) The potential of agroforestry in the provision of sustainable woodfuel in sub-saharan Africa. Current Opinion in Environmental Sustainability 6:138-147

39. Jacobson M, Ciolkosz D (2020) Plantation forestry and pellet production in Kenya. Biomass and Bioenergy 135:105519. https://doi.org/10.1016/j.biombioe.2020.105519

40. Van der Weijde T, Kamei CLA, Torres AF, Vermerris W, Dolstra O, Visser RGF, Trindade LM (2013) The potential of C4 grasses for cellulosic biofuel production. Frontiers in Plant Science 4:107. https://doi.org/10.3389/fpls.2013.00107

41. Bassam NE (2010) Handbook of bioenergy crops, a complete reference to species, development and applications. Earthscan Ltd, London, pp 240-251, 319-333, 370-376

42. Porter PA, Barry J, Samson R, Doudlah M (2008) Growing Wisconsin energy, a native grass pellet bio-heat roadmap for Wisconsin. Agrecol Corporation, Wisconsin, Madison. https://www.iatp.org/sites/default/files/258_2_104098.pdf Accessed 25 October 2019

43. Ochieng CA, Zhang Y, Nabwa JK, Otieno DI, Spillanea C (2020) Household perspectives on cookstove and fuel stacking: A qualitative study in urban and rural Kenya. Energy for Sustainable Development 59:151-159

44. Mimimoto BV (2016) IWA tiers of performance report for Mimimoto. https://www.mimimoto.nl/wpcontent/uploads/2016/02/Mimi_Moto_IWA-Tiers-of-Performance-WBT-4.2.3-Report-REV.A.pdf. Accessed 25 October 2019

45. Still D, Bentson S, Li H (2015) Results of laboratory testing of 15 cookstove designs in accordance with the ISO/IWA tiers of performance. EcoHealth 12:12-24. https://doi.org/10.1007/s10393-014-0955-6

46. Hoz DL, Perez KC, Arrieta ELC (2017) Design of a top-lit up-draft micro-gasifier biomass cookstove by thermodynamic analysis and fluent modeling. International Journal of Renewable Energy Research 7:4. https://ijrer.org/ijrer/index.php/ijrer/article/view/6268/pdf. Accessed 25 October 2019

47. Mehta Y, Richards C (2020) Effect of air flow rate and secondary air jets on the operation of TLUD gasifier cookstove. International Journal of Sustainable Energy 39(3):207-217. doi:10.1080/14786451.2019.1671388

\section{Figures}




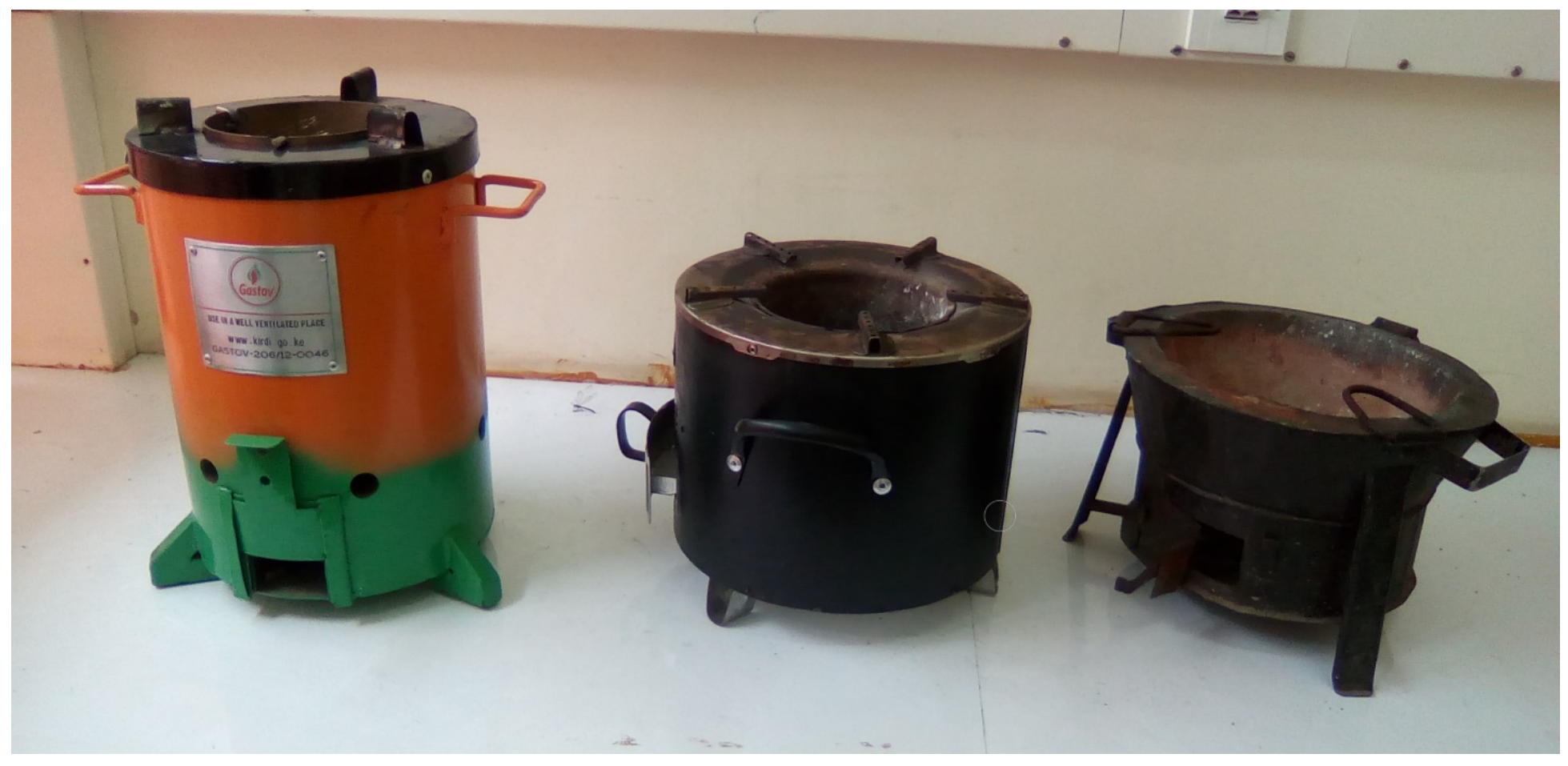

\section{Figure 1}

Gastov206, MCJ and KCJ test cookstoves

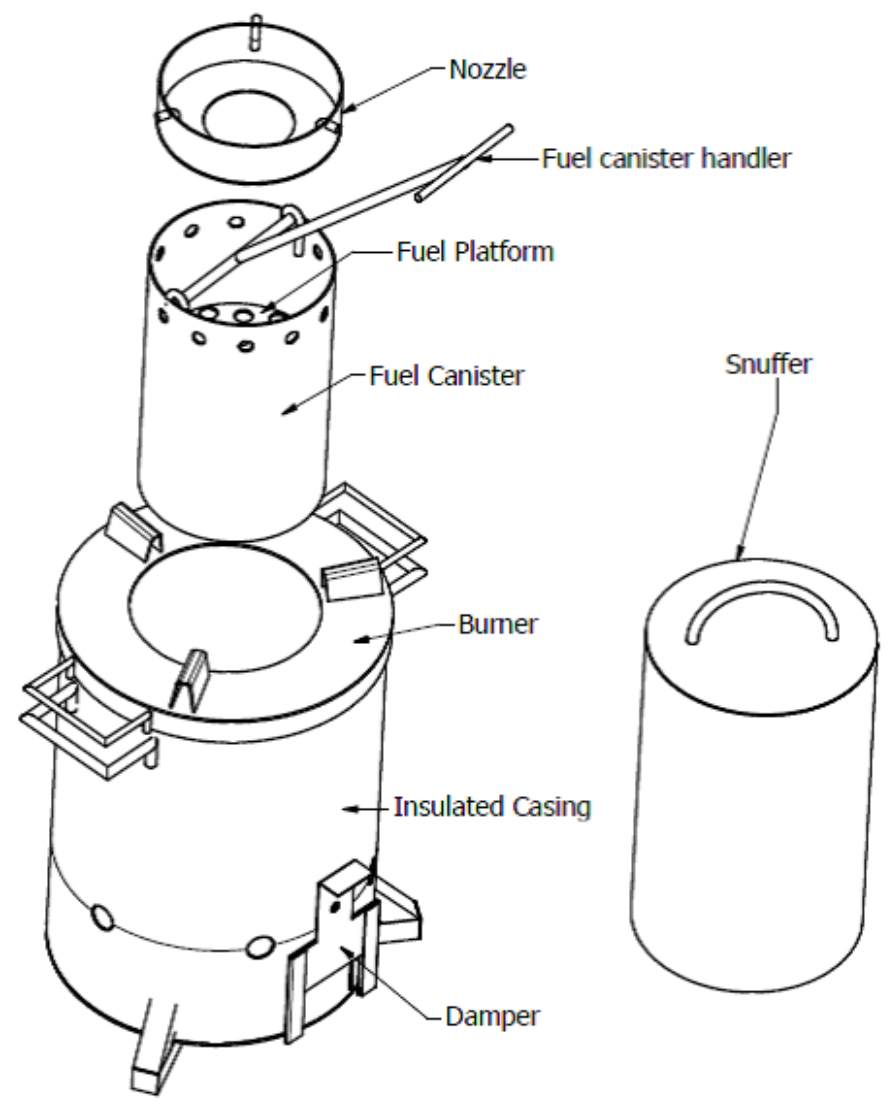

Figure 2

Exploded view of the main components of Gastov206 


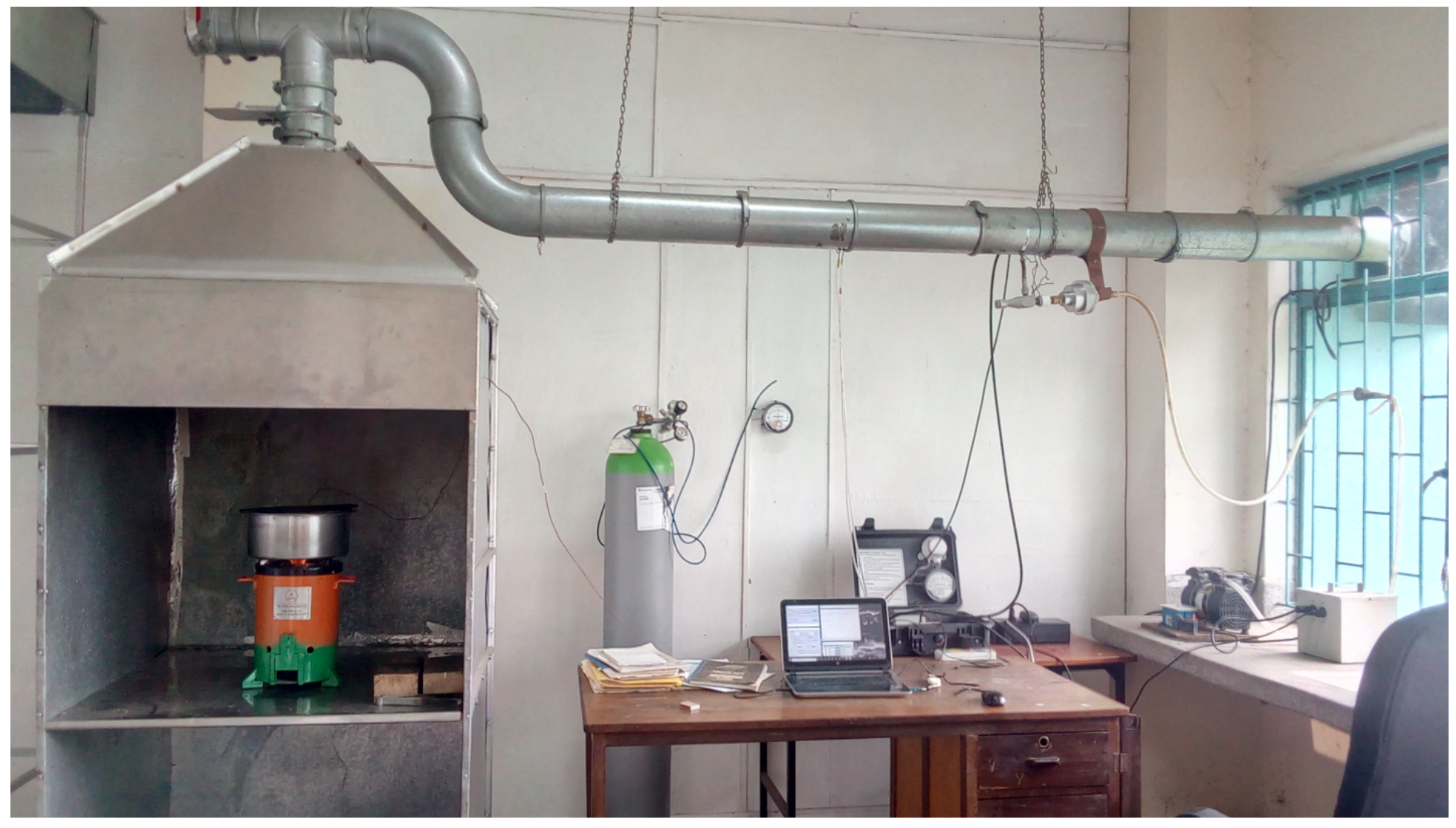

Figure 3

Set-up of test equipment

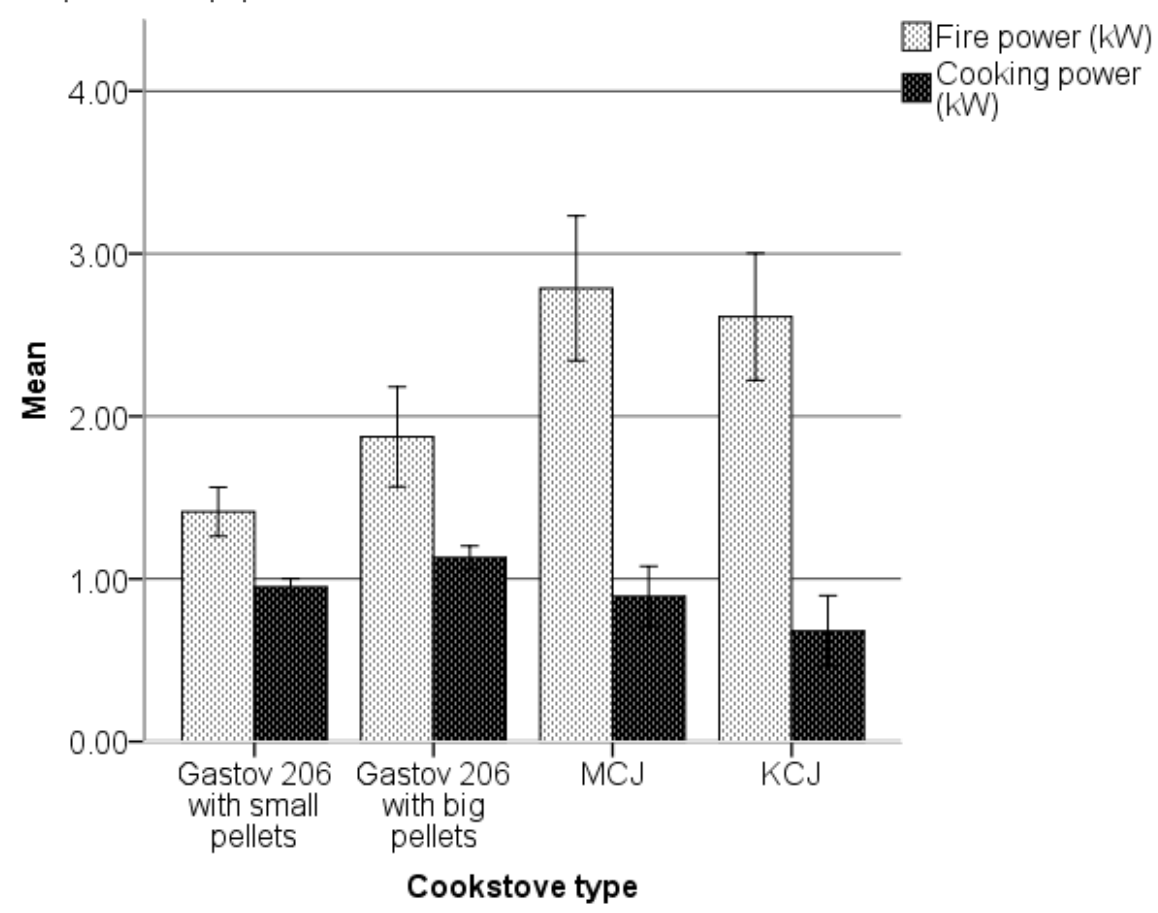

Error Bars: +/- 1 SD

\section{Figure 4}

Comparison of mean fire-power and cooking-power of cookstoves 


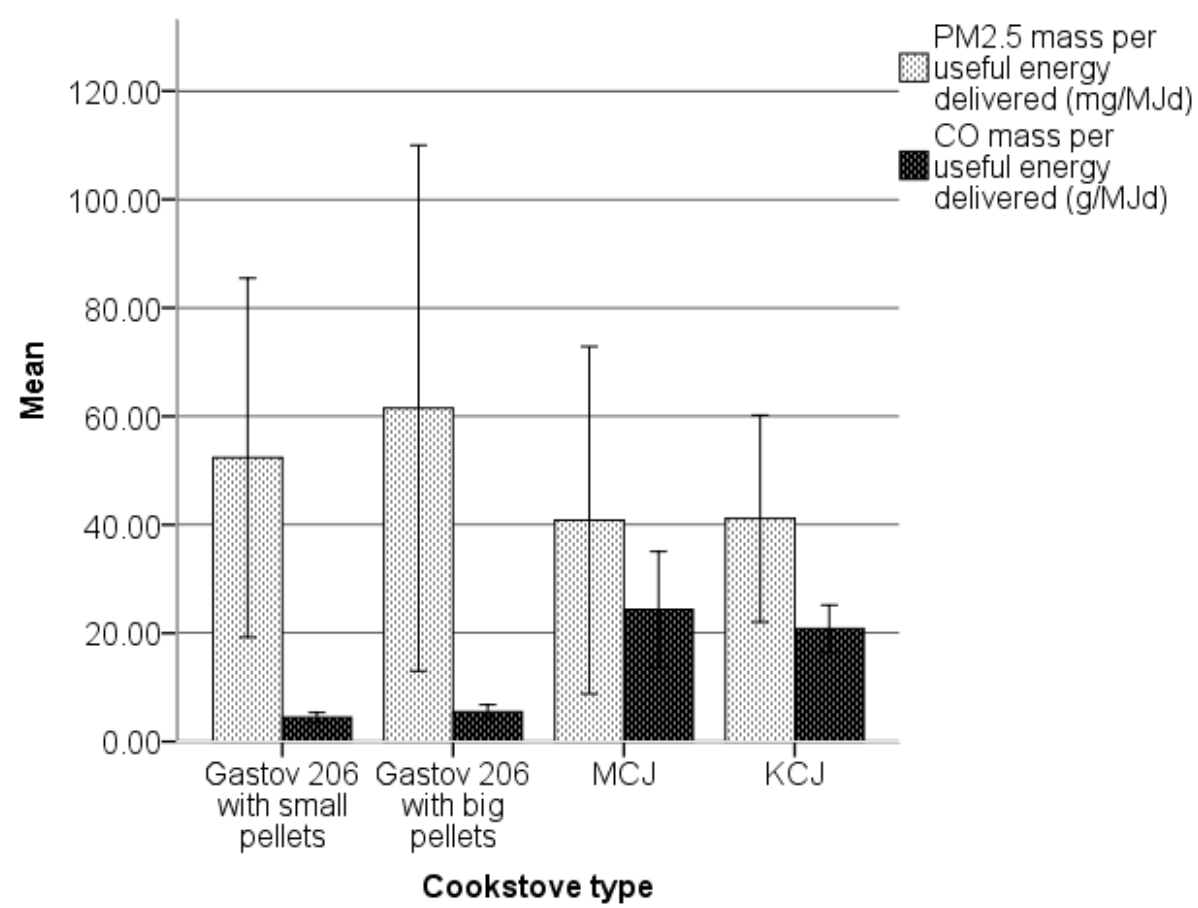

Error Bars: +/- 1 SD

\section{Figure 5}

Comparison of mean PM2.5 and CO emissions of cookstoves

Gastov206 with Size 6 pellets

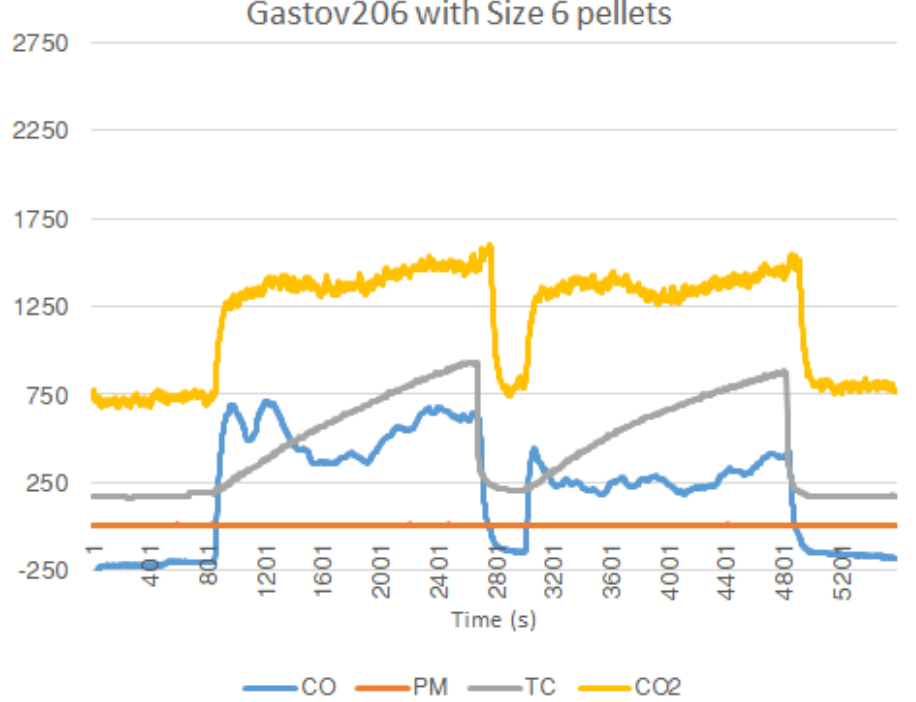

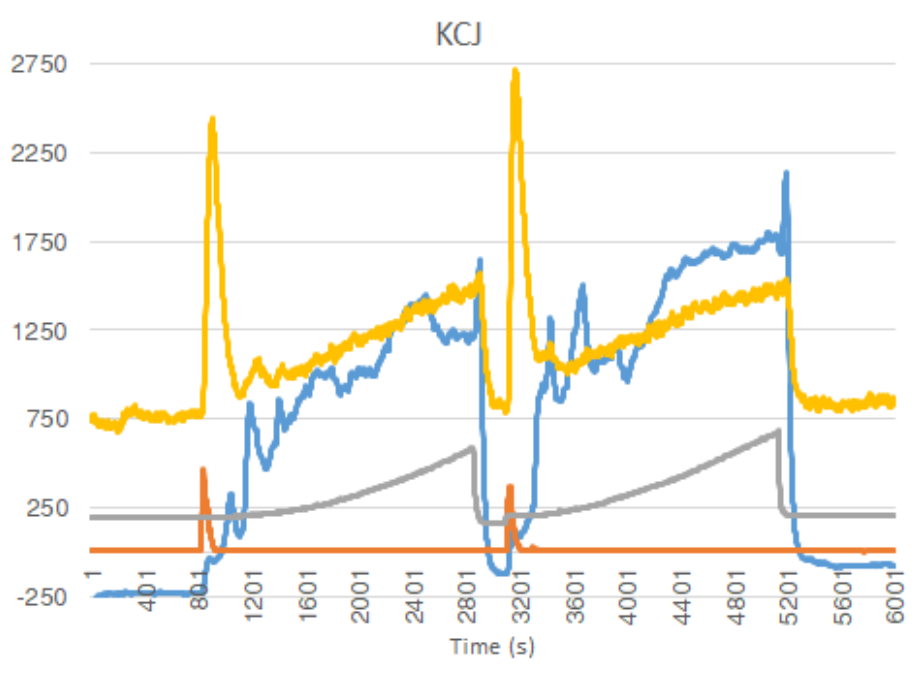

$-\mathrm{CO} \longrightarrow \mathrm{PM} \longrightarrow \mathrm{TC} \longrightarrow \mathrm{CO} 2$

\section{Figure 6}

Variation of temperature of water (TC) and emissions of $\mathrm{CO}, \mathrm{CO} 2$ and PM2.5 relative to ambient background

\section{Supplementary Files}

This is a list of supplementary files associated with this preprint. Click to download.

- appendix.docx 